Корчак О. С.

Біленець К. Є.

\title{
ДОСЛІДЖЕННЯ ТРИБОТЕХНІЧНИХ ВЛАСТИВОСТЕЙ СИЛОВИХ ЦИЛІНДРІВ ГІДРАВЛІЧНИХ ПРЕСІВ НА БАЗІ ІНЖЕНЕРНОЇ МЕТОДИКИ ОЦІНКИ ЇХ РЕСУРСУ БЕЗВІДМОВНОЇ РОБОТИ
}

У сучасних гідравлічних пресах відмови через зношування базових елементів систем керування та їх виконавчих механізмів можуть досягати 80-90% від загальної кількості всіх відмов [1]. При роботі силових циліндрів пресів відмови можуть наступати як наслідок [2]:

- зношення поверхонь до граничного стану;

- значної зміни коефіцієнта тертя та різкого його збільшення аж до схоплювання або заїдання у фрикційних і антифрикційних парах;

- кавітаційного руйнування;

- похибок монтажу тощо.

Слід зазначити, що явища, які відбуваються в парах тертя та гідравлічних елементах силових циліндрів, будуть впливати як на безвідмовність, так і на довговічність експлуатації не тільки самих циліндрів, а й деталей, що сполучаються з ними у відповідних вузлах преса [3]. У загальному випадку відмови внаслідок зношення визначаються наступними характеристиками зношування [4]:

- станом контактуючих поверхонь;

- наявністю змащувального матеріалу або іншого середовища;

- навантаженням;

- рівнем перепадів тисків;

- характером взаємних переміщень тощо.

Метою даної роботи є підвищення ресурсу безвідмовної роботи силових циліндрів гідравлічних пресів на основі дослідження їх триботехнічних властивостей, а також розробка заходів зниження загального рівня їх зношення.

Пропонована робота є продовженням досліджень, спрямованих на підвищення ресурсу безвідмовної роботи базових вузлів гідравлічних пресів та опублікованих у попередніх статтях $[5,6]$ зазначених авторів, тому залежність відмов гідравлічних циліндрів від характеристик їх зношування в даній статті не розглядаються. Однак, слід зазначити, що попередні дослідження підтверджують, що найбільш визначальними з факторів зношення є наступні:

- тиск сполучення поверхонь тертя та швидкість їх відносного переміщення у вузлах ущільнень силових гідроциліндрів [7], для яких після припрацьовування та до граничного зносу швидкість зношення не залежить від часу, тобто є постійною величиною;

- рівень перепадів тиску та пов'язані з ним кавітаційні явища для корпусів і плунжерів силових гідроциліндрів [8], для яких швидкість зношення з часом змінюється з можливим переходом зносу у руйнування внаслідок одночасного розвинення яскраво виражених зон кавітаційного роз'їдання та тріщин від втомленості при циклічному навантаженні гідравлічних елементів високим тиском робочої рідини [9].

Дослідження ресурсу безвідмовної роботи силових циліндрів, так й інших базових вузлів гідравлічних пресів доцільно здійснювати на базі інженерної методики оцінки їх триботехнічних властивостей [2].

Для проведення розрахунку ресурсу деталей машин спочатку визначається тривалість випробувань $t_{B}$ :

$$
t_{B}=\frac{T_{H} \cdot \varepsilon_{H}}{K_{n}\left(\delta_{E}-\delta_{B}\right) \cdot \varepsilon_{n}},
$$


де $T_{H}$ - нормативний ресурс роботи деталі, год;

$\varepsilon_{H}$ - помилка вимірювання зношення, мкм;

$\varepsilon_{n}-$ прийнята помилка прогнозування ресурсу, мкм;

$\delta_{E}$ - граничне відхилення розміру деталі при експлуатації, мкм;

$\delta_{B}$ - відхилення розміру деталі перед початком випробувань, мкм;

$K_{n}$ - коефіцієнт прискорення випробувань, визначається по залежності:

$$
K_{n}=\frac{K_{B} \cdot N_{B}}{K_{E} \cdot N_{E}},
$$

де $K_{B}$ - коефіцієнт використання часу при випробуваннях;

$K_{E}$ - коефіцієнт використання часу при експлуатації;

$N_{B}$ - число циклів за хвилину при випробуваннях, хв$^{-1}$;

$N_{E}$ - число циклів за хвилину при експлуатації у виробничих умовах, хв ${ }^{-1}$.

Підставивши значення параметрів в формулу (1), отримуємо час випробування деталі на зношення.

Для розрахунку ресурсу довговічності по зношуванню необхідно спочатку визначити швидкість зношення деталі:

$$
V_{3}=\frac{W_{B}-W_{O}}{t_{B}-t_{O}},
$$

де $W_{B}$ - лінійне зношення за час випробувань, мкм;

$W_{O}$ - лінійне зношення за період обкатування, мкм;

$t_{B}$ - час випробувань, визначається за формулою (1), год;

$t_{O}$ - час обкатування деталі, задається на основі експериментальних даних, год.

Далі визначається ресурс безвідмовної роботи деталі, год:

$$
T=\frac{\delta_{E}-W_{O}}{V_{3}}+t_{O} .
$$

При дослідженні ресурсу безвідмовної роботи базових вузлів гідравлічних пресів та послідуючій розробці відповідних заходів для зменшення зношення силових циліндрів необхідно базові вузли машини - силові циліндри та елементи станини - розглядати не окремо один від одного, а застосовувати системний підхід, який передбачає врахування їх взаємодії та взаємного впливу під час промислової експлуатації.

Зазначені базові елементи гідравлічних пресів взаємопов'язані між собою

- як конструктивно - робочі циліндри встановлені у верхню нерухому поперечину та своїми плунжерами спираються на рухому поперечини, а колони своїми кінцями затиснуті у верхню нерухому поперечину та взаємодіють з рухомою поперечиною по напрямним;

- так і функціонально - під час навантаження гідравлічного преса при реалізації технологічних процесів формозмінення заготовки замикання зусиль, що розвиваються, відбувається саме на станині преса, до складу якої входять всі ці базові вузли.

Таким чином, за результатами досліджень триботехнічних властивостей базових вузлів на базі інженерної методики оцінки їх ресурсів зношення відповідно до формул (1)-(4) побудовані чотири групи кривих, що являють собою залежності

- коефіцієнта прискорення випробувань $K_{n}$;

- тривалості випробувань $t_{B}$; 
- швидкості зношення деталі $V_{3}$;

- ресурсу безвідмовної роботи деталі $T$ від зусилля гідравлічного пресу $\left(P_{n}\right)$, та наведені на рис. 1-4.

Для отримання даних було використано основні параметри кувальних гідравлічних пресів ряду зусиль $30 \mathrm{MH}, 50 \mathrm{MH}, 63 \mathrm{MH}, 100 \mathrm{MH}$ і $150 \mathrm{MH}$, які знаходяться у промисловій експлуатації на підприємствах ПрАТ «Новокраматорський машинобудівний завод» та ПАТ «Енергомашспецсталь» (м. Краматорськ).

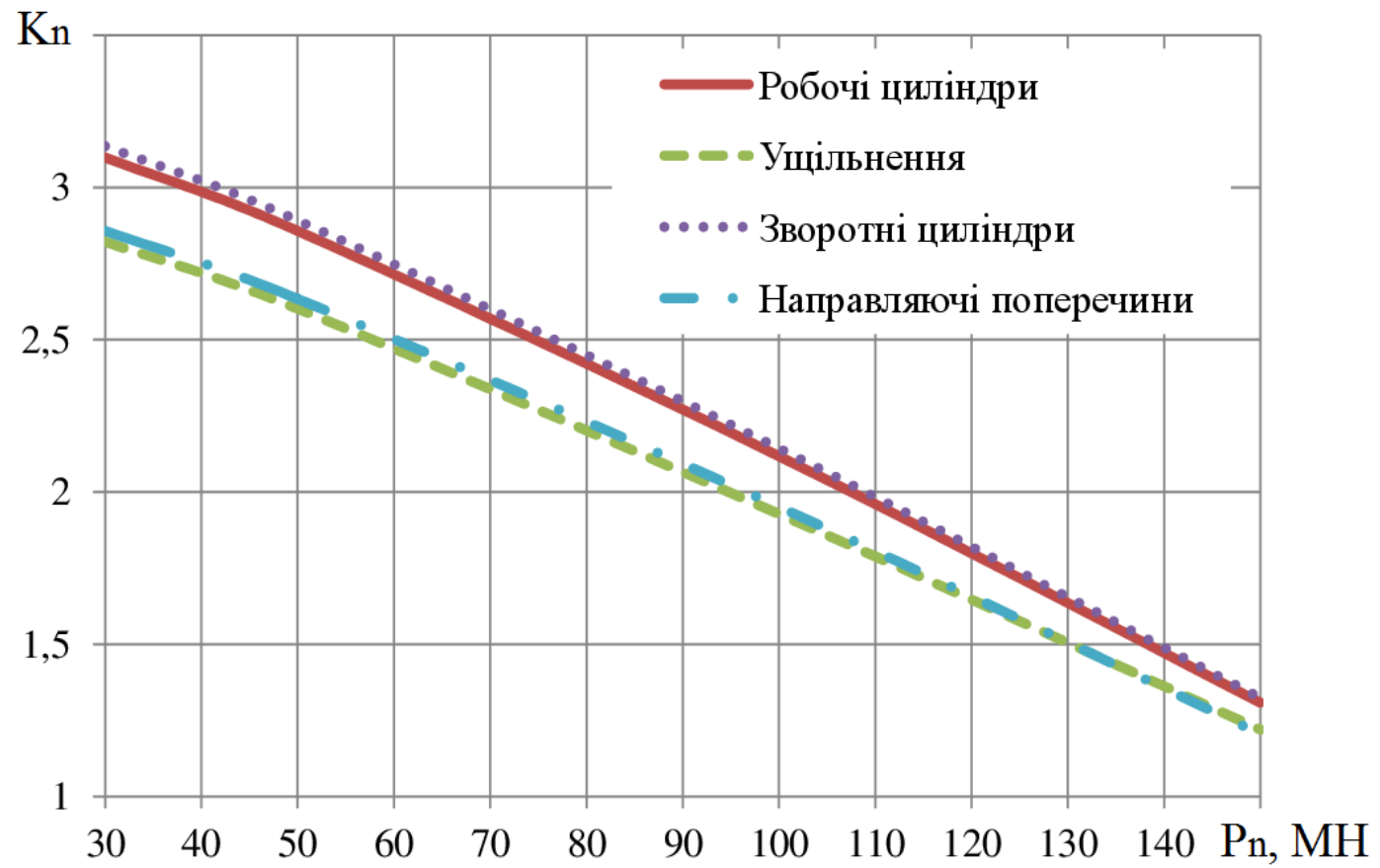

Рис. 1. Діаграма залежності коефіцієнта прискорення випробувань від зусилля преса

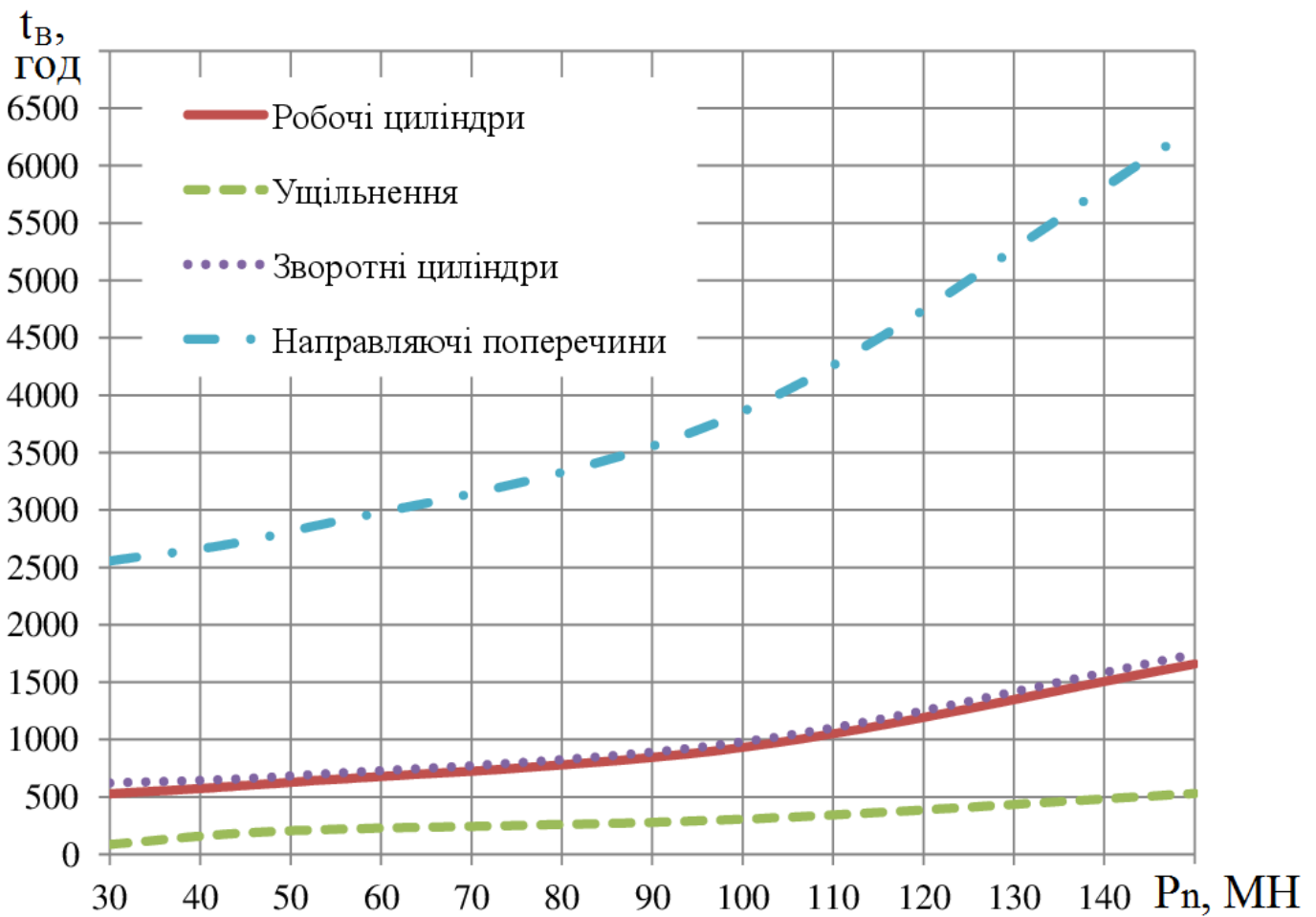

Рис. 2. Діаграма залежності тривалості випробувань від зусилля преса 


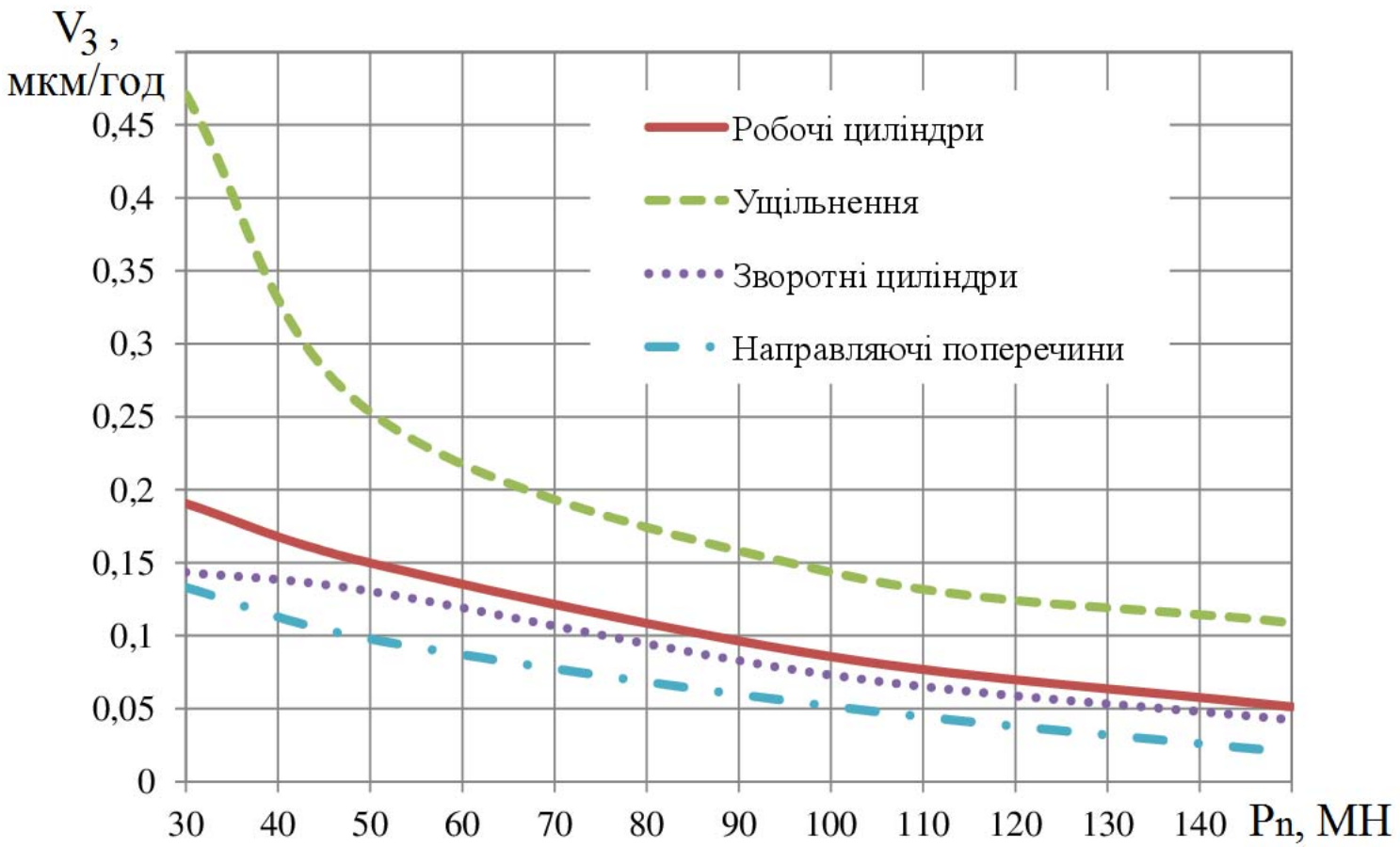

Рис. 3. Діаграма залежності швидкості зношення деталі від зусилля преса

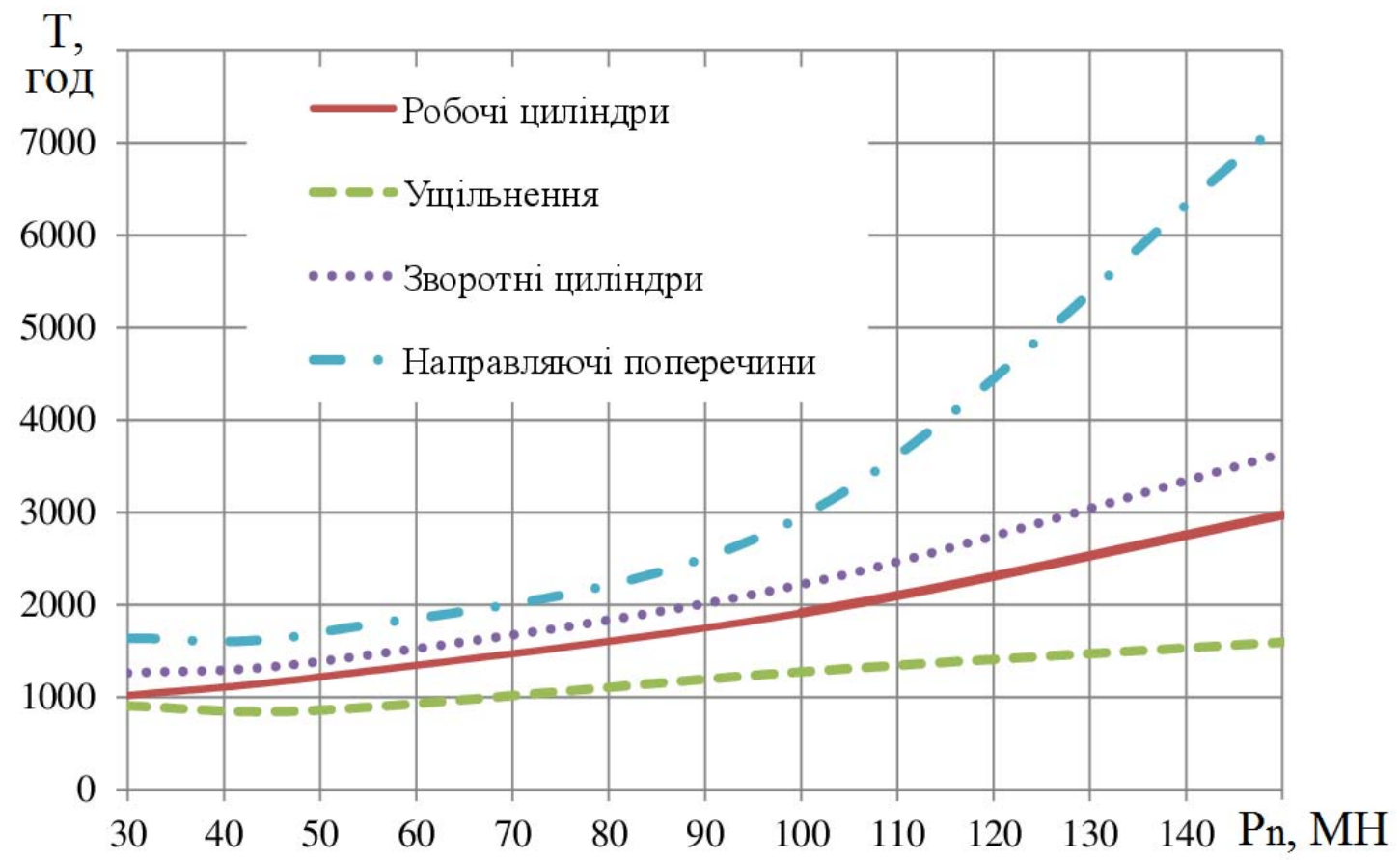

Рис. 4. Діаграма залежності ресурсу безвідмовної роботи деталі від зусилля преса

Аналіз отриманих діаграм (рис. 1-4) показує наступне.

Зі збільшенням зусилля преса коефіцієнт прискорення випробувань робочого і зворотного циліндрів, ущільнення і направляючих рухомої поперечини зменшується, що говорить о зниженні тривалості прискорених випробувань в режимі експлуатації (рис. 1).

Зі збільшенням зусилля преса тривалість випробування робочого і зворотного циліндрів збільшується і це говорить про підвищення залежності безвідмовної роботи пресу. Незначно підвищується час випробування роботи ущільнень, а направляючих рухомої поперечини - навпаки. Час до граничного зношення не залежить від швидкості зношення (рис. 2). 
Зі збільшенням зусилля преса швидкість зношення робочого і зворотного циліндрів, направляючих рухомої поперечини зменшується, що показує, що швидкість в середньому постійна, а при роботі ущільнень пресів із зусиллям до $63 \mathrm{MH}$ підвищується швидкість зношення. Слід розуміти, що після припрацювання швидкість зношення зменшується, а при рості вібрацій, температури тощо - збільшується (рис. 3).

Зі збільшенням зусилля преса ресурс безвідмовної роботи робочого і зворотного циліндрів та ущільнення збільшується, що говорить про залежність від потужності пресу. Направляючі рухомої поперечини мають великий стрибок вгору при зусиллях пресу понад $100 \mathrm{MH}$, що свідчить про значне зношення від тертя ковзанням (рис. 4).

Зазор між плунжером та внутрішньою порожниною корпусу робочого циліндра встановлюється, виходячи з умов його вільного переміщення в корпусі та відсутності перетискання робочої рідини в цьому зазорі. Внутрішня порожнина корпусу схильна кавітаційно зношуватися. Крім того в зазначеному зазорі розміщено напрямну втулку, яка запобігає перекосу плунжера при переміщенні рухомої поперечини. Антифрикційні властивості втулки та можливість підведення до неї системи змащення дозволяють значно подовжити строк експлуатації плунжера, особливо, коли до складу матеріалу втулки входить мідь. В цьому випадку окрім зниження тертя створюються умови для виникнення вибіркового переносу [2]. Експлуатаційні умови сполучення «плунжер - напрямна втулка» порушуються, як правило, 3 причини виникнення корозійного та абразивного зношення. Перший вид зношення розвивається внаслідок старіння робочих рідин, а другий - внаслідок їх недостатньої фільтрації. Тому якість робочої рідини має вирішальне значення при запобіганні зношенню пар тертя силових циліндрів. Крім того, ресурс безвідмовної роботи силових циліндрів залежить від застосованих конструкцій трубних з'єднань, які сполучають циліндри 3 джерелами високого та низького тисків. Низька довговічність й надійність трубних з'єднань внаслідок підвищеного зношення ущільнювальних елементів, їх ненадійної фіксації та виникнення витоків внаслідок перепадів тисків в трубопроводі, коливальних та гідроударних явищ призводять до передвчасних відмов силових циліндрів. Тому при конструюванні трубних з'єднань намагаються зменшити ступень їх кавітаційного зносу та подовжити термін експлуатації.

Загалом рекомендації зі збільшення ресурсу безвідмовної роботи силових циліндрів та пов'язаних 3 ними базових вузлів гідравлічних пресів можна узагальнити за допомогою нижче наведеної схеми (рис. 5).

\section{ВИСНОВКИ}

1. Проведеними в роботі дослідженнями встановлено, що зі збільшенням зусилля гідравлічного преса:

- коефіцієнт прискорення випробувань робочого і зворотного циліндрів, ущільнення і направляючих рухомої поперечини зменшується;

- тривалість випробування робочого і зворотного циліндрів збільшується, незначно підвищується час випробування роботи ущільнень, а направляючих рухомої поперечини навпаки зменшується;

- швидкість зношення робочого і зворотного циліндрів, направляючих рухомої поперечини зменшується - це показує, що швидкість в середньому постійна, а при роботі ущільнень пресів із зусиллям до 63 МН підвищується швидкість зношення;

- ресурс безвідмовної роботи робочого і зворотного циліндрів та ущільнення збільшується, а направляючі рухомої поперечини мають великий стрибок вгору при зусиллях пресу понад $100 \mathrm{MH}$, що свідчить про значне зношення від тертя ковзанням.

2. Розробка заходів постійного автоматичного контролю та запобігання наближення роботи гідравлічного преса до аварійної границі $є$ вирішальним фактором забезпечення безвідмовної роботи його базових вузлів при умові раціонального їх проектування та відповідності показників роботи заданим експлуатаційним характеристикам. 


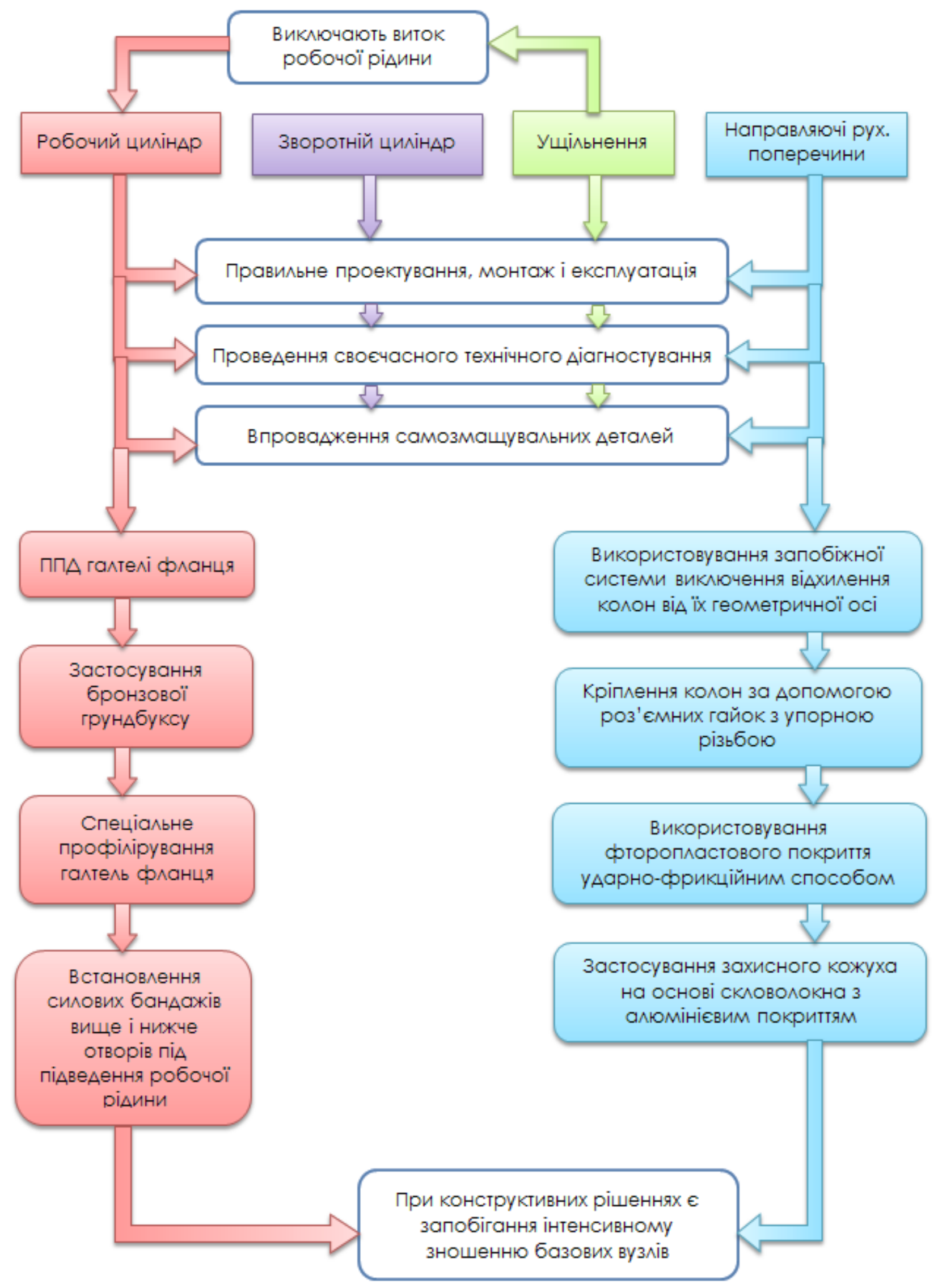

Рис. 5. Рекомендації зі збільшення ресурсу безвідмовної роботи силових циліндрів та пов'язаних з ними базових вузлів гідравлічних пресів 


\section{СПИСОК ВИКОРИСТАНОЇ ЛІТЕРАТУРИ}

1. Анализ отказов, предупреждение разрушений и восстановление базовых деталей мощных гидравлических прессов / Н. П. Коркин, Д. А. Кулагин, А. П. Моисеев, И. А. Сурков // Технология легких сплавов. - № 1-2. 2006. - C. 181-189.

2. Трение, износ и смазка (трибология и триботехника) / А. В Чичинадзе, С. М Берлинер, Э. Д Браун, Н. А. Буше ; под ред. А. В. Чичинадзе. - М. : Машиностроение, 2003. - 576 с.

3. Сурков А. И. Обеспечение прочностной надежности базовых деталей мощных гидравлических прессов на стадиях проектирования и эксплуатации / А. И. Сурков, А. Н. Курович, И. А. Сурков // Тяжелое машиностроение. - № 5. - 2003. - С. 35-37.

4. Гойдо М. Е. Технические решения для улучшения характеристик работы гидравлических прессов / М. Е. Гойдо, В. В. Бодров, Р. М. Багаутдинов // Заготовительные производства в машиностроении. - М. : Машиностроение, 2015. - № 4. - С. 25-32.

5. Корчак О. С. Розвиток методів збільшення ресурсу безвідмовної роботи базових вузлів гідравлічних пресів / О. С. Корчак, К. С. Біленещь // Вісник ДДМА. - 2018. - № 2 (44). -С. 125-128.

6. Корчак О. С. Дослідження умов експлуатащії та причин виникнення зношення в силових циліндрах гідравлічних пресів / О. С. Корчак, М. І. Нагієв, К. С. Біленець // Обработка материалов давлением : сб. науч. трудов. - Краматорск : ДГМА, 2018. - № 2 (47). - С. 173-175.

7. Новиков В. И. Повышение надежности работь деталей, отвечающих за перемещение подвижной поперечинь в гидравлическом ковочном прессе / В. И. Новиков, В. И. Кадочников, Е. В. Куликова // КШП. ОМД. - № 2. - 2012. - C. 24-28.

8. An investigation of highly pressurized transient fluid flow in pipelines / Z. Ouchiha, J. C. Loraud, A. Ghezal, M. Kessal and other // International Journal of Pressure Vessels and Piping. - Elsevier, 2012. - Vol. 92. - P. 106-114.

9. Vullo V. Circular Cylinders and Pressure Vessels : Stress Analysis and Design. - Switzerland: Springer International Publishing, 2014. -409 p.

\section{REFERENCES}

1. Analiz otkazov, preduprezhdenie razrushenij i vosstanovlenie bazovyh detalej moshhnyh gidravlicheskih pressov / N. P. Korkin, D. A. Kulagin, A. P. Moiseev, I. A. Surkov // Tehnologija legkih splavov. - № 1-2. - 2006. S. 181-189.

2. Trenie, iznos i smazka (tribologija $i$ tribotehnika) / A. V Chichinadze, C. M Berliner, Je. D Braun, N. A. Bushe; pod red. A. V. Chichinadze. - M. : Mashinostroenie, 2003. - $576 \mathrm{~s}$.

3. Surkov A. I. Obespechenie prochnostnoj nadezhnosti bazovyh detalej moshhnyh gidravlicheskih pressov na stadijah proektirovanija i jekspluatacii / A. I. Surkov, A. N. Kurovich, I. A. Surkov // Tjazheloe mashinostroenie. - № 5. 2003. - S. 35-37.

4. Gojdo M. E. Tehnicheskie reshenija dlja uluchshenija harakteristik raboty gidravlicheskih pressov / M. E. Gojdo, V. V. Bodrov, R. M. Bagautdinov // Zagotovitel'nye proizvodstva v mashinostroenii. - M. : Mashinostroenie, 2015. - № 4. - S. 25-32.

5. Korchak O. S. Rozvytok metodiv zbil'shennja resursu bezvidmovnoi' roboty bazovyh vuzliv gidravlichnyh presiv / O. S. Korchak, K. Je. Bilenec' // Visnyk DDMA. - 2018. - № 2 (44). - S. 125-128.

6. Korchak O. S. Doslidzhennja umov ekspluatacii' ta prychyn vynyknennja znoshennja v sylovyh cylindrah gidravlichnyh presiv / O. S. Korchak, M. I. Nagijev, K. Je. Bilenec' // Obrabotka materyalov davlenyem : sb. nauch. trudov. - Kramatorsk: DGMA, 2018. - № 2 (47). - S. 173-175.

7. Novikov V.I. Povyshenie nadezhnosti raboty detalej, otvechajushhih za peremeshhenie podvizhnoj poperechiny $v$ gidravlicheskom kovochnom presse / V. I. Novikov, V. I. Kadoshnikov, E. V. Kulikova // KShP. OMD. № 2. - 2012. - S. 24-28.

8. An investigation of highly pressurized transient fluid flow in pipelines / Z. Ouchiha, J. C. Loraud, A. Ghezal, M. Kessal and other // International Journal of Pressure Vessels and Piping. - Elsevier, 2012. - Vol. 92. - P. 106-114.

9. Vullo V. Circular Cylinders and Pressure Vessels : Stress Analysis and Design. - Switzerland: Springer International Publishing, 2014. - 409 p.

Корчак О. С. - д-р техн. наук, доц. ДДМА;

Біленець К. Є. - магістр ДДМА.

ДДМА - Донбаська державна машинобудівна академія, м. Краматорськ.

E-mail: helen_korchak@ukr.net

Стаття надійшла до редакиії 11.01.2019 р. 